\title{
O necesară precizare în raport de forma de vinovăție cu care sunt săvârșite formele agravate ale infracțiunii de zădărnicire a combaterii bolilor
}

\section{Drd. George-Alexandru Lazăr Facultatea de Drept, Universitatea din București}

Rezumat: Având în vedere publicarea articolului „,Modificările propuse pentru modificarea Codului Penal în vederea combaterii răspândirii coronavirusului" imediat după apariția textelor de lege, aducem câteva clarificări, după cântărirea mai îndeaproape a unor particularități ale textului de lege.

In principal, considerăm că variantele agravate prevăzute de art. 352 alin. (5) și (6) C.pen. se săvârșesc cu intenție depășită, iar în ipoteza în care rezultatul mai grav, vătămarea corporală sau decesul, este urmărit sau acceptat de agent, se va reține un concurs intre zădărnicirea combaterii bolilor și vătămare corporală sau omor.

Totodată, apreciem că forma de vinovăție pentru art. 352 alin. (2) C.pen. nu poate fi praeterintenția, deoarece urmarea imediată nu este săvârșită din culpă, ci este o urmare firească a infectării unei persoane.

Tot astfel, considerăm că lovirea este absorbită în art. 352 alin. (2) și (3) C.pen., dacă urmarea produsă este lezarea integrității fizice, pentru care au fost necesare cel mult 90 de zile de ingrijiri medicale.

Cuvinte-cheie: zădărnicirea combaterii bolilor, modificare, fals în declarații, omisiunea declarării unor informații, O.U.G. nr. 28/2020.

\section{A necessary clarification regarding the type of guilt specific to the aggravated forms of the crime of thwarting the repression of diseases}

\begin{abstract}
Considering that we published the article with the title „Changes proposed for the Criminal Code to combat the spreading of the coronavirus" immediately after the project became public, we are bringing some clarifications, after closely observing some of the particularities of the new statues.

Chiefly, we believe that the aggravated forms contained in art. 352 alin. (5) and (6) Criminal Code are committed with criminal intent, and when the more severe result, death or severe injury, is accepted or pursued by the agent, he or she will be charged with two crimes, thwarting the repression of diseases and murder or severe injury.

On the other hand, we believe that the type of guilt specific to art. 352 alin. (2) Criminal Code cannot be praeterintention, because the more severe result of the crime is not due to negligence, but the usual result of infecting another person.

We believe the crime of violence is absorbed in art. 352 alin. (2) and (3) Criminal Code, if the result of the crime is physical injury that requires no more than 90 days of medical care.
\end{abstract}

Keywords: thwarting the repression of diseases, false declarations, the failure to declare information, Emergency Ordonnance no. 28/2020. 
După reflectarea asupra unora dintre particularitățile art. 352 C.p., în forma adoptată de legiuitor, am considerat oportună formularea câtorva precizări suplimentare sau nuanțări ale opiniilor inițial exprimate ${ }^{1}$.

Un prim aspect vizează aria de aplicare a noțiunii de „carantină” utilizată în art. 352 alin. (1) C.p. În articolul publicat, am arătat că definiția dată de alin. (9) reia în esență definiția din art. 1 al Ordinului nr. 414/2020. Diferența esențială între cele două definiții, însă, privește izolarea la domiciliu, care este expres menționată în Ordin, însă nu poate fi acoperită de formularea art. 352 alin. (9) C.p. Mențiunea expresă din Cod cu privire la locuri special amenajate pentru carantină restrânge sfera de aplicare a textului de lege la carantina stricto sensu și nu include izolarea la domiciliu, soluție pe care o considerăm criticabilă.

Un al doilea aspect important privește variantele agravate de la alin. (5) și (6) ale art. 352 C.p., respectiv producerea unui rezultat specific prin nerespectarea măsurilor de carantină, spitalizare, de prevenire și combatere a bolilor infectocontagioase, rezultat ce constă în vătămarea corporală sau decesul uneia sau a mai multor persoane.

În textul publicat am arătat că aceste variante agravate sunt săvârșite cu intenție, ceea ce exclude concursul de infracțiuni cu vătămarea corporală și omorul, operând o absorbție legală, opinie pe care înțelegem să o nuanțăm. Pentru a oferi această soluție, am plecat de la analiza art. 352 alin. (3) C.p. în contextul actualei pandemii de coronavirus. În această paradigmă, este improbabil ca cineva să transmită cu intenție virusul unei alte persoane și să nu accepte, în același timp producerea unei vătămări corporale sau a decesului. Concluzia derivă din faptul că virusul poate fi mortal, chiar și pentru persoane fără alte boli, iar posibilitatea producerii decesului sau a unei vătămări este previzibilă, iar de cele mai multe ori, acceptată.

$\mathrm{Cu}$ toate acestea, întrucât normele juridice adoptate nu sunt temporare, ele nu au aptitudinea de a se aplica doar în timpul pandemiei de coronavirus, ci pentru toate bolile infectocontagioase. Or, pentru o boală cu o mortalitate mai redusă în cazul transmiterii, pot fi mai ușor imaginate situații în care persoana urmărește infectarea victimei sau o acceptă, dar nu acceptă și posibilitatea unei vătămări corporale sau a decesului (spre exemplu, în cazul unor forme de gripă).

În plus, limitele de pedeapsă prevăzute de legiuitor în art. 352 alin. (5) - (7) C.p. corespund infracțiunilor din culpă și praeterintenționate din titlul I al Părţii Speciale a Codului. Pentru nerespectarea din culpă a măsurilor de prevenire și combatere a bolii, care produc

\footnotetext{
${ }^{1}$ Articolul inițial poate fi consultat la adresa https://drept.unibuc.ro/dyn_img/aubd/Modificările\%20aduse\%20Codului\%20Penal\%20prin\%20Ordonanța\%20 de\%20Urgență.pdf.
} 
vătămarea corporală a uneia sau a mai multor persoane, pedeapsa este închisoarea de la 1 la 5 ani, iar dacă a produs decesul de la 2 la 7 ani [în acest caz, la fel ca limitele din art. 192 alin. (2) C.p., prevăzute pentru uciderea din culpă în variantă agravată].

Pentru nerespectarea cu intenție măsurilor de carantină sau spitalizare, de prevenire și combatere a bolii intenționate, care produc vătămarea corporală a uneia sau mai multor persoane pedeapsa este închisoarea de la 2 la 7 ani, iar dacă se produce decesul de la 5 la 12 ani. Acestea corespund vătămării corporale [de la 2 la 7 ani în art. 194 alin. (1) C.p.] și lovirii sau vătămărilor cauzatoare de moarte (art. 195 C.p.).

În plus, formularea legiuitorului, respectiv sintagma „dacă prin faptă s-a produs vătămarea corporală sau moartea" este specifică infracțiunilor praeterintenționate, astfel că vom concluziona că variantele agravate prevăzute în art. 352 alin. (5) și (6) C.p. se săvârșesc cu intenție depășită.

O consecință firească este că acceptarea rezultatului mai grav, al vătămării corporale sau decesului, sau urmărirea producerii acestui rezultat, va da naștere unui concurs de infracțiuni cu vătămarea corporală sau cu omorul.

Nu putem fi de acord cu opinia exprimată în doctrină în sensul că fapta incriminată la alin. (2) al art. 352 C.p. este praeterintenţionată² ${ }^{2}$ Urmarea impusă de textul de lege, a răspândirii bolii, nu este, în opinia noastră, o urmare mai gravă, din culpă, ci reprezintă urmarea firească a infectării unei persoane. Faptul că în acest caz se poate ajunge la o suprapunere între alin. (2) și (3) nu este de natură a schimba această concluzie, deoarece alin. (3) cuprinde suficiente diferențe pentru a justifica o aplicare distinctă, fără a îngloba conținutul alin. (2). Altfel spus, transmiterea bolii se poate realiza și fără nerespectarea măsurilor de prevenire și combatere a bolii, pentru multe dintre bolile infectocontagioase astfel de norme nefiind adoptate. Din nou, considerăm esențial a analiza norma și în afara contextului prezentei pandemii.

În fine, atragem atenția asupra unei particularități în raport de infracțiunea de lovire, reglementată de art. 193 C.p. Legiuitorul a prevăzut variante agravate praeterintenționate pentru producerea unui rezultat mai grav constând în vătămarea corporală sau decesul victimei, însă nu a prevăzut nicio regulă pentru infracțiunea de lovire sau alte vătămări. Din interpretarea sistematică a art. 352 C.p. rezultă că lovirea este absorbită în cuprinsul art. 352 alin. (2) sau (3)

\footnotetext{
${ }^{2}$ Opinie exprimată în R. Slăvoiu, Modificarea dispozițiilor art. 352 Cod penal prin O.U.G. nr. 28/200. Sau, de ce este periculoasă supranormarea, disponibil pe www.juridice.ro.
} 
C.p., atunci când urmarea produsă este o lezare a integrității fizice evaluată la cel mult 90 de zile de îngrijiri medicale.

Deși lovirea se absoarbe în infracțiuni precum viol sau tâlhărie, care utilizează noțiunea de constrângere sau violență, voința legiuitorului în sensul unei absorbții pare să acopere și nerespectarea măsurilor de prevenire și combatere a bolilor infectocontagioase sau transmiterea unei asemenea boli de către o persoană care știa că suferă de o astfel de boală. Chiar dacă am putea accepta această soluție pentru alin. (3) al textului de lege, în cazul alin. (2) este dificil de conciliat absorbția naturală între infectarea unei persoane cu o boală infectocontagioasă prin nerespectarea măsurilor de combatere și lovire. Desigur, pornind de la premisa că boala este atât de gravă încât a impus adoptarea de norme de combatere, poate fi acceptată și soluţia adoptată prin O.U.G. nr. 28/2020, însă considerăm că poate genera soluții discutabile în funcție de boala transmisă.

Materialul a fost publicat în revista online a Facultăţii de Drept, $\underline{\text { AUBD - Forum Juridic nr. }}$ $\underline{1 / 2020 .}$ 